\title{
원조조정의 의미와 우리의 향후 추진방향
}

장현식 (KOICA 협력정책반장)

\section{I. 서 론}

개발협력의 역사를 살펴보면 개도국 정부나 조직, 그리고 국민들이 스스로 도우려고 하는 의지와 마 음을 가지고 있을 때 그 효과가 가장 높다는 것을 보여주고 있다. 즉 원조의 효율성을 유지하기 위해 개 도국민들은 자신들의 개발정책과 프로그램에 주인의식(Ownership)을 가지고 있어야 한다는 것이다.

개도국의 주인의식을 지속시키기 위해서는 공여국간의 협력이 필수불가결한데, 그 이유를 살펴보 면 공여국들의 수원국에 대한 서로 다른 정책, 절차, 예산, 시기 및 경쟁심, 접근방법에 대한 의견 불일 치, 또한 수원국의 공여국과의 조정에 대한 소극적인 태도로 인하여 사업의 효율성이 저하되고 있다고 지적되기 때문이다. 현재 많은 원조기관들은 수원국 정부와 민간기관의 주인의식과 참여에 기초하 여 수원국과의 파트너쉽을 강조하기 위해 원조조정 과정을 중요시하고 있으며, 이를 위해 좀더 적극적 이고 체계적으로 접근하고자 여러 조치를 취하고 있다. 또한 선진 원조기관들은 수원국에 거주하는 자 체 해외사무소에 좀더 많은 재량권을 부여함으로써 원조조정에 많은 역점을 두고 있다.

반면에 베트남을 비롯한 몇몇 수원국들은 강도는 다르지만 외부의 원조기관들과 자신들의 전략수 립 및 조정과정에 리더쉽을 발휘하기도 한다. 원조조정의 형태가 어떤 모습인가에 상관없이 공통적으 로 필요한 사항은 개도국 스스로 자신들의 개발전략 및 적절한 사업 프로젝트나 프로그램을 수립할 수 있는 능력배양이 우선되어야 한다는 것이다.

1) Stephen Browne는 원조조정이 잘 이루어지지 않을 경우 발생할 수 있는 부정적인 요소로 기술적인 면, 재정적인 면, 그리고 인적자원적인 측면으로 대분하여 설명하고 있다. "Foreign Aid in Practice" (New York Univ. Pres, 1990), p139.

2) Hyun-sik Chang, Arthur M. Fell and Michael Laird(1999), A Comparison of Management Systems For Development Cooperation in OECD/DAC Members, OECD, p.30 
위에서 언급한 공여국과 수원국과의 조정 외에도 원조조정의 측면을 공여국내 ODA관련 기관간의 일관성제고 관점에서 접근할 수 있다. 대개 공여국에서 $\mathrm{ODA}$ 담당기관이 적으면 적을수록 원조정책의 일관성이 유지되어 조정이 용이하다고 한다. 이는 ODA 관련 부처가 많으면 많을수록 국내조정이 쉽 지 않다는 것을 의미한달. 현재 선진국 원조기관들은 국내조정을 용이하게 수행하기 위해 조직개편 을 하거나 아니면 국내원조조정 체제를 재조정하고 있다.

이와 같은 점을 고려하여 $\mathrm{OECD} / \mathrm{DAC}$ 는 파트너쉽과 원조조정의 의미와 중요성을 인지하고 1960 년 창설 시부터 원조조정을 주요한 업무로 여겨 왔으며, 원조조정에 관한 가이드라인을 만들어 원조조 정에 대한 기본적인 책임은 수원국에 있다고 명시하였다.3. 또한 '98년에는 관련 주제에 관한 포럼을 주최하여 파트너쉽에 관한 11 개 체크리스트를 수립하였으며, 2003년에는 DAC의 원조관행 특별작업 반이 작성한 보고서를 중심으로 수원국의 주인의식 강화 및 효과적 원조집행을 위한 로마선언을 마련 하였다 ${ }^{4)}$.

본 소고에서는 원조의 효율성을 강조하기 위한 원조조정의 개념과 종류를 살펴보고, 또한 현행 선진 공 여국과 우리나라의 조정체계를 비교한 후 이를 기초로 향후 우리의 효율적인 조정방안을 살펴보고자 한다.

\section{II. 원조조정의 개념과 종류}

원조조정은 원조사업을 실시하는데 있어서 각 관련 기관간에 원조정책, 전략 및 특정사업에 관해 사전에 조율을 실시하는 과정을 의미하며, 크게 국내적 조정과 국제적 조정으로 대분할 수 있다. 국내 적 조정은 국내 관련기관간의 업무조정을 의미하는 반면, 국제적 조정은 아국과 타 국가간의 조정이라 할 수 있는데, 동 조정은 정책수준별로 다시 정책대화(Joint Consultation), 사업별 조정 (Concertation) 및 프로젝트(Operational Coordination) 조정으로 대분할 수 있다5).

\section{1. 국내적 조정}

현재 각 공여국은 어떤 형태로든지 자국내 원조정책에 관한 조정을 실시하고 있지만 각 ODA 담당

3) OECD/DAC, "DAC Principles for Effective Aid" "Guiding Principles for Aid Coordination with Developing Countries" p.25.

4) 로마선언은 "ownership, country by country approach, 협력수단의 다양성 인정” 이라는 3원칙을 수립하였으며, 이를 통해 원조 공여국들의 집행방 식에 조화를 기함으로 원조의 효과를 제고하자는 선언이라 할 수 있다.

5) Browne, Stephen, "Foreign Aid in Practice"(New York Univ. Press, 1990), pp.137-138

6) 현재 원조사업에 대한 조정은 $\mathrm{OECD} / \mathrm{DAC}$ 에서 가장 역점을 두고 추진하고 있다. 그중에서도 $\mathrm{DAC}$ 회원국중 15 개국이 포함된 $\mathrm{EU}$ 회원국들이 가장 활발하 게 원조에 관한 조정을 실시하고 있다. 뿐만아니라 $\mathrm{UN}$, 세계은행과 같은 다자간 원조기관들도 양자간원조기관과의 원조관련 조정회의를 개최하고 있다. 
부처가 자신의 원조방법 및 수단을 고집하는 현 상황에서는 실제로 조정이 잘 이루어지지 않고 있다.). 현재 원조사업에 대한 조정은 $\mathrm{OECD} / \mathrm{DAC}$ 에서 가장 역점을 두고 추진하고 있다. 그 중에서도 $\mathrm{DAC}$ 회 원국중 15 개국이 포함된 $\mathrm{EU}$ 회원국들이 가장 활발하게 원조에 관한 조정을 실시하고 있다. 뿐만 아니라 $\mathrm{UN}$, 세계은행과 같은 다자간 원조기관들도 양자간 원조기관과의 원조관련 조정회의를 개최하고 있다.

국내 원조실시기관간의 원조 조정은 대개 원조를 담당하는 부처가 많이 존재할 경우 그 필요성이 더욱 두드러 진다고 할 수 있다.

그 형태로는 크게 두 가지이며, 미국, 호주, 카나다와 같이 대다수의 원조업무를 외무성이나 외무 성의 산하기관이 실시하는 국가의 경우이며 이때 대내조정은 쉽게 이루어지고 있는 반면, 원조담당 부처가 많은 일본, 스페인, 프랑스의 경우 조정을 담당하는 제도적 장치가 마련되어 있지만 대내 조정 이 쉽게 이루어지지 않고 있다. 일반적으로 한 국가내 원조 담당부처가 많을 경우, 각료회의와 같은 가 장 고위급레벨에서 원조사업에 관한 조정이 실시되지만 사업 성격 및 절차의 차이 때문에 쉽게 의견이 조정되지 못하고 있닥.

본고에서는 미국, 프랑스, 덴마크, 일본의 경우를 살펴보고 마지막으로 우리의 현황을 살펴보고자 한다.

\section{가. 미국의 경우 ${ }^{8)}$}

미국의 경우 ‘98년 외무 개혁과 구조조정 법안의 실행에 따라, 국무부와 국제개발청(USAID)이 원 조조정 업무를 담당하고 있으며, 개발과 경제 원조를 미국 외교정책의 핵심으로 확립하기 위한 노력 을 가속화하고 있다. 현재 국무부와 USAID 두 기관 사이의 협력과 조정을 향상하기 위한 단계가 (정 책, 프로그램, 예산, 실행 절차에서) 진행되고 있다.

반면 주제별(아프가니스탄, 부채, 재난 구호 등)로는 수요에 따라서 임시적으로, 실용적으로 구성되 며, 특별히 중요성이 대두되는 이슈들에 대해서는 관련 기관들이 협력하고 있다. 또한 전략기획, 예산 조정, 혹은 특정 기관간 실행 협정 등에 대한 빈번한 협력으로 인해 목표대상 기관들이 최소한으로 협 력할 수 있는 협의의 단계가 미리 설정되기도 한다. 그리고 중앙 기관들(관리 예산부서 Office of Management and Budget, 국가안보위원회 National Security Council)이 서로 협력하거나 협력 하지 않는 것에 대해서 감독하고 비평하기도 한다.

이렇게 서로 다른 조정 기관들이 미국 정부의 기관간 개발 조정에 기여하기는 하지만, 상호적인 조

7) 일반적으로 한 국가내 원조 담당부처가 많을 경우, 각료회의와 같은 가장 고위급레벨에서 원조사업에 관한 조정이 실시되지만 사업 성격 및 절차의 차이 때문에 쉽게 의견이 조정되지 못하고 있다.

8) OECD(2002), DAC Peer Review of United States 
정을 위한 체계적인 절차를 확립하지는 못하고 있는 형편이다. 회의의 안건이나 결과는 회의를 주최하 는 기관에만 달려있는 경향이 있으며, 이러한 기관들은 사무적인 안건에만 집중하고, 개발 공동체의 비 공직 인사들은 초대하지 않는 경우가 대부분이다. 특히 국가안보위원회는 행정부 전반에 걸쳐서 기 관간 조정을 향상시키기 위한 임무를 가진다.

$\mathrm{ODA}$ 실시현장(수원국)에서의 ODA 실시기관간의 조정은 그 지역의 미 대사관에 의해서 이루어지 고 있다. 대사관들은 “국가 팀(Country Team)" 구조에 의존하는데, 이러한 구조는 넓은 시야를 수용 하기 위해서 그 지역의 모든 단체의 대표들을 포함한다. 지역의 상황이나 인력에 따라서, 국가팀은 분 과조로 나뉘기도 하고, 임무수행계획에 따른 전략에 따라서 나누어지기도 한다.

\section{나. 프랑스의 경우9)}

프랑스의 경우 범부처간 조정은 원칙적으로, 범 부처간 국제개발협력 위원회(CICID: Interministerial Committee for International Co-operation and Development)에서 담당하며 국무 총리의 주최로 일년에 한번씩 회의가 열린다.

CICID에는 국제 협력의 임무를 맡은 모든 각료들과, 대통령 비서가 참여한다. 외무부와 재정경제 산업부는 공동으로 위원회에게 사무국 서비스를 제공하고 있으나, 이 임무만을 담당하는 전임직원을 배치하지는 않고 있다. 동 위원회는 자주 만나지는 않으나, 공식적, 비공식적으로 각 부처들이 협력하 도록 도와주고 있다. 일반적으로 CICID 회의 전에 범 부처간의 조정은 계속되고 있으며, 위원회 자체 는 이러한 조정의 결과를 비준하기 위한 회의를 개최한다. 절차의 평가나 조화 등 구체적인 문제들을 다루는 분과위원회도 설립되었다.

CICID와는 상관없이, 운영적인 측면에서 조정특성을 가진 구조들이 많이 있다. 예를 들면 우선연 대기금(FSP: Priority Solidarity Fund)의 전략가이드 위원회는 프로젝트 위원회와 함께 범부처간 정 책 관리를 촉진한다. 반면 외무부 및 재정경제산업부 대표, 국외영토 사무국, 의회, 경제와 재정 전문 가로 지명된 인사, $\mathrm{AFD}$ 직원 대표들이 참여하는 $\mathrm{AFD}$ 의 '감독 이사회(Supervisory Board)'는 개발국 $(\mathrm{AFD})$ 의 기술적 지원을 받아 구조조정 프로그램과 $\mathrm{C} 2 \mathrm{D}$ 프로그램(부채 감소와 개발에 대한 계약, C2D: Contracts for Dept Reduction and Development)에 대한 조정을 실시하고 있다.

$\mathrm{NGO}$ 와의 조정은 $\mathrm{HCCI}$ (국제협력을 위한 고위위원회: High Council for International Cooperation) 이외에도, 다른 많은 기관에서 시민사회 기구들과의 조정이 다루어지고 있다. DGCID 내 에서는 '비정부협력과' 가 시민사회의 파트너들과 프랑스 중앙정부 하위레벨 부처들과의 관계를 책임

9) OECD(2004), DAC Peer Review of France 
지고 있다. AFD역시 ‘Clup de OSI’ 라고 불리는 협력 구조를 가지고 있다. 프랑코포니와 협력 국무장 관이 의장을 맡고 있는 '개발 협력 위원회'라는 합작 협의 기관의 형태 안에서 시민 사회 기관들과의 대 화가 이루어지고 있고, 여기에는 시민사회 기구의 대표와 개발 관련 부처의 장관들이 포함된다.

\section{다. 덴마크의 경우 ${ }^{10}$}

덴마크 개발협력의 특징은 중앙집권적이고 잘 짜여진 조직 시스템으로 되어있는 점이다. 다른 $\mathrm{DAC}$ 회원국의 원조 시스템과 비교했을 때, 덴마크는 다음의 두 가지 특징을 가지고 있다. 첫째, 덴마 크의 정부가 거의 모든 $\mathrm{ODA}$ 에 대한 책임 및 전략과 운영상의 의사결정을 독점적으로 이끌고 있지만, 반면에 다른 회원국과 비교해서 $\mathrm{NGO}$ 의 영향력이 약하다는 점이다. 둘째, 덴마크 정부 안에서 모든 리더쉽이나 운영은 외무부 내부의 세 부서 중 한 부서에 집중되어 있다. 그 세 개의 주요 행정부서는 북 그룹(North Group), 남그룹(South Group), 덴마크 통상위원회(Danish Trade Council)이고, 이 들 모두는 행정 서비스 사무국에 의해서 지원을 받는다.

덴마크 개발협력의 주안점은 남그룹에 있고, 이 그룹은 아프리카, 아시아, 라틴아메리카, 중동, 태 평양과의 양자간, 다자간 개발협력을 담당한다. 남그룹은 외무부 장관에게 직접보고를 하는 장관급의 공무원에 의해 이끌어지고 있으며, 두 명의 차관급이 전체적으로 양자, 다자간 정책을 책임지고 있다.

지역부서(남부 아프리카, 동서중부 아프리카, 동남아시아, 중동, 라틴아프리카와 북부 아프리카의 5 개부서)와 각각의 대사관이 동시에 남그룹에서 원조 책임을 진다. 현재 덴마크는 원조의 책임을 현장 으로 많이 이양하는 분권화를 추진하고 있기 때문에 각 지역부서의 직원들은 운영적인 측면에서 전략 적이고 정책적인 측면으로 업무를 전향하고, 기술고문서비스(TSA: Technical Advisory Services)팀 에 속한 기술직 직원은 점차 각 대사관의 요구에 따라서 업무를 진행하고 있다.

\section{라. 일본의 경우 ${ }^{11}$}

새로운 $\mathrm{ODA}$ 대강(大綱)은 'ODA에 관한 부처간 협의 포럼' 을 활용하여 ODA 관련부처와 기관들 의 협력을 강화하는 것을 목표로 하고 있다. 물론 ODA에 관련된 기관간의 조정의 목적은 정책 일관성 을 확보하기 위한 것이다. 현재 외무성에 ODA 관련 기구들을 조정하는데 핵심적인 역할이 배정되어 있지만, 경제통상산업성 또한 통상과 투자에 대한 정책을 형성함으로써 일본의 경제 협력 시스템에서 중요한 역할을 하고 있다. 반면에 농림수산성은 많은 ODA관련 부처의 하나로서 국내의 식량과 농업 정책을 담당하고, 개발운영에 있어서 기술전문가를 제공하기도 한다. 농림수산성은 개발 프로젝트와 국내 정책의 이익의 관련성에 대해서 자문을 받기도 하는데, 주로 국내 정책의 이익에 주안점을 둔다.

10) OECD(2003), DAC Peer Review of Denmark

11) OECD(2004), DAC Peer Review of Japan 
개발에 관련되어 있는 세 부처 중에서 외무성이 핵심적인 조정의 역할을 하고, JICA와 일본국제협 력은행(JBIC)이 운영에 있어서 핵심적인 역할을 수행하고 있다. 외무 장관은, 각 부서의 장에 의해서 운영되고 있는 10 개의 외무관련 사무국의 운영책임을 지고 있다. 경제협력국(ECB: Economic $\mathrm{Co}-$ operation Bureau), 다자협력과(Multilateral Cooperation Department), 경제국(Economic Affairs Bureau), 지역별 사무국이 개발관련 운영의 책임을 진다.

경제협력국 $(\mathrm{ECB})$ 은 $\mathrm{ODA}$ 정책형성과 $\mathrm{ODA}$ 예산절차에 있어서 기구간 조정 등을 담당한다. 최근 $\mathrm{ECB}$ 의 개발기관 간의 조정능력을 강화하기 위한 개혁이 있었으나, 인력 부족이 여전히 문제가 되고 있 다. 현재 $\mathrm{ECB}$ 운영은 원조 방법 (무상원조, 기술협력, 차관와 개발협력 부서)을 중심으로 조직되어 있 으나, 점차적으로 국가적 차원에서의 전략적 조정의 중요성이 부각되고 있다. 국가 차원의 강조는, 외 무성 지역별 사무소-운영기관-현장 사이를 어떻게 조정할 것인가에 대한 운영적 문제도 불러일으킨 다. 예를 들면, $\mathrm{JICA}$ 와 JBIC는 국가별로 조직되어 있는데 $\mathrm{ECB}$ 내부는 그렇지 않다는 것이 문제이다.

또한, 많은 공공 기관들을 조정하기 위해서 일본 개발협력 시스템 안에서 관리조직의 네트워크가 만들어져 있다. 도쿄내의 기관에서 조정기구가 거의 모든 행정 수준에서 설립되었다. 이러한 정부 내 의 새롭고 야심찬 조정 체계는 사무국과 부서 차원에서도 실행이 되고 있는 중이며, 외무성은 최근 다 른 ODA 부서들과의 협력도 공고히 하였다.

〈범부처간 조정〉

\begin{tabular}{|c|c|c|c|}
\hline 기 구 & 책 임 & 참 여 자 & 비고 \\
\hline $\begin{array}{c}\text { 해외경제협력관련 } \\
\text { 각료회의 }\end{array}$ & 기초 경제개발정책 & $\begin{array}{l}\text { 관방장관이 의장, } \\
\text { 8개의 경제 협력관련 } \\
\text { 부처 장관 참여 }\end{array}$ & $\begin{array}{l}\text { 2000년 12월 설립 } \\
\text { 필요할 때 회의개최 }\end{array}$ \\
\hline $\begin{array}{l}\text { ODA에 대한 } \\
\text { 범부처간 회의 }\end{array}$ & $\begin{array}{l}\mathrm{ODA} \text { 에 관한 주요 이슈 } \\
\text { 들 논의 }\end{array}$ & $\begin{array}{l}\text { ODA사무국의 장, 내각, } \\
\text { 외무성 장관이 의장 }\end{array}$ & $\begin{array}{l}\text { 2000년 3월 설립 } \\
\text { 필요할 때 회의개최 }\end{array}$ \\
\hline $\begin{array}{c}\text { ODA에 대한 } \\
\text { 범부처간 회의를 위한 } \\
\text { 사무국 회의 }\end{array}$ & $\begin{array}{l}\text { 범부처간 회의를 위해 } \\
\text { ODA 제안 협상 }\end{array}$ & $\begin{array}{l}12 \text { 개의 ODA 부서장, } \\
\text { 외무성 장관이 의장 }\end{array}$ & $\begin{array}{l}\text { 범부처간 회의보다 자주 } \\
\text { 회의개최 }\end{array}$ \\
\hline 기술협력 전문가 회의 & $\begin{array}{l}\text { 관련 프로젝트에 대해서 } \\
\text { 견해를 교환, 협력 }\end{array}$ & $\begin{array}{l}12 \text { 개의 평가 부서의 장, } \\
\text { 옵서버 : 학자, 전문가, NGO }\end{array}$ & 1997년 4월 설립 \\
\hline ODA 평가 전문가 회의 & $\begin{array}{l}\text { 평가에 대한 가이드라인 작성, } \\
\text { 평가결과 검토 }\end{array}$ & $\begin{array}{l}\text { 외무성, 재무성, } \\
\text { 경제통산성, JICA, JBIC, } \\
\text { 일본무역보험 재정협력 } \\
\text { 부서의 장 }\end{array}$ & 2001년 7월 설립 \\
\hline 재정협력 전문가회의 & $\begin{array}{l}\text { 무상원조, 차관, OOF, } \\
\text { 수출차관에 대한 논의 및 조정 }\end{array}$ & $\begin{array}{l}\text { 외무성 장관이 의장, } \\
\text { 시민사회 참여 }\end{array}$ & 2002년 11월 설립 \\
\hline 전체적 ODA 전략이사회 & $\begin{array}{l}\text { ODA 전략 이슈에 대한 } \\
\text { 외무성 공공 자문 위원회 }\end{array}$ & $\begin{array}{l}\text { 외무성 장관이 의장, } \\
\text { 부대신, 시민사회 참여 }\end{array}$ & $\begin{array}{l}\text { 2002년 6월설립 } \\
\text { 목표대상 국가 결정의 역할 }\end{array}$ \\
\hline
\end{tabular}

출처: OECD/DAC Peer Review of Japan, p50 
수원국에서의 $\mathrm{ODA}$ 담당기관간의 조정으로는 모든 기관들이 정기적으로 모일 수 있도록 하는 “ODA 타스크포스"를 모든 대사관이 설립하도록 되어 있다. 이러한 특수 임무조직에서는 전문가, $\mathrm{NGO}$, 현장에서의 일본 전문가들과 함께 네트워크를 형성하도록 되어 있다. 공식적인 역할은 정보 수 집, 전략 개발, 지역의 정부와의 협상, 다른 공여국과의 협상이다. JBIC나 JICA와 같이 이와 비슷한 역할을 가지고 있는 기관들도 이들과 함께 현장에서 협력하고 있다. 이는 현장으로의 권한 이양이라 는 맥락에서, 일본의 원조 조정 절차의 분권화 노력의 일환이라 할 수 있다.

\section{마. 우리의 경우}

우리의 경우를 살펴보면 대외원조사업 관련 기간의 의견을 반영하기 위하여 여러 회의기구가 설치 되어 있으나 유·무상 원조에 대한 협의.조정을 위한 협의기구가 없는 실정이달. 목표와 기본 방침의 불명확성이 도출되고 있으며, 정책결정의 이원화로 비효율성이 나타나고 있다 ${ }^{13)}$.

반면에 ODA 관련법을 제정하여 원활한 원조조정을 위한 여러 시도가 있었다. 예를 들면, 외교부는 2004년 유.무상원조 총괄조정기능을 담당하는 내용이 포함된 가칭 “국제개발협력법”을 제정하조자 하였으나, 재정경제부 등 관련 부처의 반대로 무산되었다.

이는 일본처럼 무상과 유상원조, 양자 및 다자간 원조의 실시기관이 상이하기 때문에 원조조정이 용이하지 않기 때문이라 할 수 있다 ${ }^{14)}$. 특히 유 - 무상 원조정책을 수립하는 외교부와 재경부간에 원조 관련 조정이 사업 성격의 차이로 잘 이루어지지 못하고 있다. 이를 효율적으로 달성하기 위해서는 조 직상으로 유 - 무상 원조를 담당하는 기관을 일원화하는 제도적 개혁이 우선되어야 하며, 이것이 현실 적으로 불가능할 경우에는 관련 부처들간의 $\mathrm{ODA}$ 관련 정책을 조정할 수 있는 제도적 장치가 마련되어 야 할 것이다.

\section{2. 국제적 조정}

\section{가. 정책대화}

일반적으로 국가와 국가간의 정책대화는 다자간 조정체계의 형식을 띠고 있다. 잘 알려진 다자간 조정체계는 매년 혹은 반년에 한 번씩 개최되는 World Bank의 CG(Consultative Group)와 UNDP 의 Round Table이라 할 수 있다. 이 포럼은 수원국에서 개최되는 크고 작은 많은 회의 결과를 잘 수

12) 현재 우리나라는 대외경제장관회의, 대외경제협력기금 운용위원회, KOICA 이사회가 있지만 유.무상 원조계획, 유.무상 원조 지원기준 및 대상선정, 유. 무상 원조협력방안 등을 논의하지 못하고 있다.(감사원 감사 결과 처분 요구서, 2004, 12)

13) 현재 무상원조는 매년 연간사업계획에 의거 사업을 시행하고 있는 반면, 유상원조는 지원 guideline하에 사업별로 심사, 추진여부가 결정되어 유.무상 간 상호 연계성과 원조의 효과가 미흡한 실정이다.

14) Kim, Sang-Tae \& Seddon, David, ODA Policy and Practice: The Republic of Korea (2004) pp.347-348 
용하고 있다. 또 다른 조정체계를 살펴보면 특정지역을 위한 SPA(Special Programm of Assistance for Africa), 그리고 특정분야를 위한 CGIAR(Consultative Group on International Agricultural Research)를 들 수 있다. 반면 다자간 원조조정체계의 한 몫을 담당하고 있는 $\mathrm{OECD} / \mathrm{DAC}$ 는 정책적인 면에서 사업에 관한 회원국간의 원조조정 역할을 담당하고 있으며, $\mathrm{EU}($ European Union) 회원국들은 공식적으로 자신들의 원조 정책에 관한 조정을 실시하고 있다.

\section{1) World Bank Consultative Group(CG) Meetings}

World Bank는 1963년부터 CG 회의를 주최하고 있다. 동 회의의 가장 중요한 목적은 공여국과 개 도국간의 정책대화를 강화하고, 개발을 지원하기 위한 재원을 확보하는 것이다. 또한 CG회의를 통해 공여국들이 수원국의 확인한 재정적 규모를 감당하도록 약속을 받아내고, 수원국의 일반적인 경제 및 개발관련 의견을 교환하는 것이다. 최근에 가장 활발하게 취급되는 의제는 분야별 계획 그리고 참여적 개발과 좋은 통치(PDGG)에 관련된 것이다.

CG회의는 World Bank에서 이끌어 가지만, 가끔씩 관련 수원국의 책임자가 담당하기도 하며, 대 부분 회의는 파리에 있는 World Bank 사무소에서 개최된다. 그러나 라틴 아메리카를 위한 회의는 위 싱턴에서, 그리고 아시아. 태평양국가를 위한 회의는 동경에서 개최되기도 한다. 그러나 동 회의는 수 원국에서 더 많이 개최할 예정인데, 그 이유는 이를 통해 수원국의 국회의원, 민간분야, 민간기업 및 $\mathrm{NGO}$ 들의 보다 적극적인 참석을 유도할 수 있기 때문이다.

\section{2) UNDP Round Table (RT)}

최빈국과의 정책대화 및 재원조달을 위한 UNDP의 주요한 수단으로 Round Table을 들 수 있다. 동 회의는 ' 70 년대 초에 시작되었으며, UNDP의 협조로 수원국들의 노력으로 확대발전 되었다. RT는 World Bank의 CG회의와는 달리 수원국이 이끌어 나가고 있다. 반면에 UNDP는 동 회의가 결과 중 심적으로 진행되고 있는지 혹은 각 공여국의 약속이 잘 지켜지고 있는지 매우 세밀하게 점검하고 있 다. 통상적으로 RT는 2 년마다 개최되며, 개최장소는 제네바이고, 공여국으로부터 기술적, 재정적 도 움이 요구되는 장기적 개발 이슈를 다루고 있다. 분야별 RT는 필요성이 제기되면 수원국 자체에서 개 최되기도 한다. 최근에 $\mathrm{RT}$ 에 민간기업 및 $\mathrm{NGO}$ 까지 참여폭이 확대되었으며, 재원조달에 더 많은 강 조점을 주고 있다.

\section{3) SPA(Special Programme of Assistance for Africa)}

World Bank의 SPA는 1987년에 설립되었으며, sub-Sahara 아프리카 지역에의 원조조정을 위한 가장 중요한 포럼의 하나로 발전되었다. 동 회의의 목표는 경제개혁을 실시하고자 노력하는 국가들에 
대한 시기적절한 재원조달과 공여국 원조에 대한 효율성을 제고하는데 있다. SPA 의제는 경제개혁의 개발맥락 속에 이를 지지하는 특별한 주제를 위한 작업반의 형성을 어떻게 하는가에 있다. SPA는 또 한 수원국의 주인의식과 원조의 효과를 강화하기 위해서 경제개혁 프로그램의 고안, 시간별 절차 그 리고 실행 방법을 알고자 한다.

\section{4) CGIAR(The Consultative Group on International Agricultural Research)}

CGIAR은 '71년에 설립되었으며, 공여국과 개도국들의 모든 공적, 민간 조직간의 비공식적 결합체 라 할 수 있다. CGIAR은 16 개의 국제 농업연구센타간의 네트워크로 구성되어 있으며, 동 센타들은 농 업, 식량정책, 천연자원관리에 관한 전략 및 응용 연구를 전문적으로 실시하고 있고 있다. CGIAR의 목 표는 이와 같은 분야의 연구를 통해 개도국의 식량안보를 위한 지속적 농업에 대한 연구를 실시하는데 있다. 현재 CGIAR에는 FAO, UNDP, UNEP 및 World Bank등이 공동 스폰서로 참여하고 있다.

\section{5) OECD/DAC}

$\mathrm{OECD} / \mathrm{DAC}$ 은 양자간 회원국들의 지속적 발전을 지원하기 위한 공동의 노력을 경주하고 있으며, 회원국간 원조조정에 중요한 역할을 수행하고 있다. $\mathrm{OECD} / \mathrm{DAC}$ 는 다음 4 개의 원칙을 가지고 있다. 첫째, 권위를 가진 정책지침서를 채택하고, 둘째, 회원국의 원조정책에 대한 동료심사를 정기적으로 실시하며, 셋째, 상호간의 경험을 공유하기 위한 포럼을 개최하거나 회원국들에게 관심이 있는 정책 및 관리적인 이슈에 대한 국제적인 합의를 도출하고, 마지막으로 개도국에게 공여되는 ODA나 다른 재원에 관한 통계 및 보고서를 출판하고 있다.

\section{6) EU(European Union)}

현재 22 개 $\mathrm{DAC}$ 회원국 중 15 개 회원국(그리스포함)이 $\mathrm{EU}$ 의 회원국이며, $\mathrm{EU}$ 의 마스트리히조약 (1993)은 EU Commission과 EU 회원국들이 개발협력에 관한 정책에 대해 조정할 것과 원조 프로그 램에 대한 상호간 자문을 하도록 명하고 있다. 이를 잘 실현하기 위해 현재 EU Commission과 회원 국간에 정책 및 실시 상 여러 가지 측면에서 대화를 계속하고 있다. 이와 같은 원조조정은 여러 레벨에 서 실시되고 있는데, 예를 들면, 수원국에 거주하는 자국의 해외사무소간, 회원국 정부의 원조기관간, 그리고 원조담당 장관간의 대화 등 여러 형태를 지니고 있다.

\section{나. 사업별 조정 및 프로젝트 조정}

사업별 조정이나 프로젝트 조정은 정책대화에 비해 낮은 수준의 조정을 의미하며, 현재 공여국은 프로젝트나 프로그램 상 여러 형태로 조정을 실시하고 있다. 


\section{1) 협조융자(Co-financing)}

협조융자는 양자 혹은 다자 공여국들이 어떤 프로젝트에 대한 공동 파이낸싱을 실시하는 것을 말하 며, 각 공여국들이 자신들의 파이낸싱에 대해 통제권한을 가진다. 또한 공여국들은 World Bank와 협 조융자를 하기도 한다. 협조융자의 장점은 첫째, 재원의 고갈문제를 완화할 수 있고, 둘째, 개도국들에 게 가능한 한 다양한 재정지원기관에 접할 수 있어 개발전략 상 우선적인 순위를 갖는 사업을 가능한 한 유리한 조건으로 수행할 수 있으며, 셋째, 공여국의 관점에서 볼 때 세계은행과 같은 기관과 함께 참가토록 함으로써 개도국에 제공하는 차관에 따르는 위험을 줄 일 수 있다 ${ }^{15}$.

\section{2) 합동융자(Joint financing)}

여러 양자기관이나 혹은 다자간 원조기관들이 함께 재원을 합쳐서 파이낸싱을 하는 것을 말하며, 이때 일반적으로 한 기관이 조달을 포함하여 모든 것을 책임지는 주 기관이 된다. 동 융자의 장점으로 는 첫째, 한 종류만으로 지원하는 경우보다 총 지원액을 증가시킬 수 있으며, 둘째, 많은 재정지원을 필요로 하지만 양허적 조건의 융자가 더 이상 정당화되지 않는 개도국에게 적당하며, 셋째, 시장의 재 정조건보다 유리하며, 넷째, 일부는 연계할 수 있다는 것이다.

\section{3) 평행융자(Parallel Financing)}

둘 이상의 공여국들이 같은 프로젝트에 직접적으로 협력자금을 제공하는 것을 말하며, 이때 공여국 들은 프로젝트의 서로 다른 분야를 담당한다. 예를 들면 어떤 공여국은 인프라를 제공하며, 다른 공여 국은 기술협력을 제공하는 것을 의미한다.

\section{4) Multi-bi Project}

공여국이 다자간 원조기관에서 실시하는 프로젝트에 특별한 재정적 지원을 하는 경우를 의미한다. 이때 공여국이 제공하는 것은 단지 재정적 지원뿐이며, 다자간 원조기관의 사업실시에 책임을 지지 않 는다. 예를 들면 KOICA에서 UNDP와 협력하여 사업을 실시한다고 할 때, 이때 KOICA는 단지 재정 적인 지원을 하며, 모든 사업 실시는 UNDP에서 하는 것을 말한다. 


\section{5) Associate Experts}

공여국들이 자신들의 비용으로 다자간 원조기관에 파견하는 전문가를 말한다. 예를 들면 KOICA 에서 $\mathrm{ESCAP}$ 에 행정경비를 포함한 제비용을 제공하면서 직원을 파견하는 경우를 들 수 있다.

6) Integrated Experts

어떤 공여국의 전문가가 다른 공여국에 파견되어 근무하는 것을 의미한다.

\section{7) Ad hoc Collaboration}

정부간 혹은 지역간 협력체에서의 협력을 의미한다.

\section{8) 공여국 그룹(Donor Group)}

노르딕국가(덴마크, 핀란드, 아이스랜드, 노르웨이, 스웨덴)들은 상호 협력을 통해 프로젝트에 대해 공동으로 재정적 지원(Nordic Development Fund)을 실시한다. 또한 소위 'Like-minded Group' (Belgium, Canada, Denmark, Finland, the Netherland, Norway, Sweden)은 개발협력에 대한 일반적인 접근법에 대해 토의한다.

\section{9) 합동 평가(Joint Evaluation)}

둘 이상의 공여국 혹은 다자간 원조기관들과 함께 평가를 실시하는 것을 말한다.

\section{III. 향후 추진 방향}

지금까지 논의한 점을 고려하여 우리 정부의 향후 바람직한 조정방향을 살펴보고자한다.

\section{1. 국내적 조정}

국내조정은 원조정책의 일관성을 위해서 반드시 필요한 제도적 장치라 할 수 있다. 선진국의 경우 국내조정을 강화하기 위한 방안으로는 첫째, 제도적인 측면에서 $\mathrm{ODA}$ 를 담당하는 기관에 대한 조직적 인 통합을 실시하거나, 둘째, 관련기관간의 정책대화를 강화하고 있으며, 셋째, 법적인 측면에서 $\mathrm{ODA}$ 정책의 정책방향과 목표설정이 포함된 ODA관련 전략틀을 수립하고 있는 것을 알 수 있다. 이와 같은 방향을 고려하여 우리의 조정 강화방안을 살펴보면 다음과 같다. 


\section{가. ODA 담당기관의 통합}

먼저 $\mathrm{ODA}$ 담당기관간의 조직적 통합방안을 살펴보면 우리와 원조조직 및 형태가 유사한 일본이 유·무상 원조조직을 통합하려는 의지를 표명하고 있고, 원조규모가 우리와 비슷한 대만이 유·무상 원 조조직을 통합하여 실시하는 점을 고려시 향후에 무 · 유상을 실시하는 기관간의 통합도 생각해 볼 수 있 다. 통합 방안으로는 유상원조보다는 무상원조가 향후 개발협력의 나아갈 방향인 바 통합된 원조정책의 수립은 외교부, 그리고 집행기관은 $\mathrm{KOICA}$ 로 일원화 하는 것이 효율성을 높일 수 있으리라 판단된다.

\section{나. 정책대화 강화}

우리의 경우 무상협력은 외교부가 정책수립, 집행은 $\mathrm{KOICA}$ 가 하고 있으며, 유상원조의 경우 정책 수립은 재경부, 집행은 수출입은행으로 이원화되어있다. 또한 부처간의 ODA에 대한 서로 다른 인식 및 통합에 대한 부담 때문에 통합된 원조조직을 가지는 것은 단기간에 이루어 질 수 없을 것으로 판단 된다. 그러나 통합 전이라도 무.유상 원조실시 정책상의 조정 및 타 정책과 원조정책간의 일관성을 유 지하기 위해 관련 부처간의 정기적인 회의를 더욱 강화하여야 할 것이다.

부처간의 업무조정을 위한 회의는 참석범위별로 고위급과 실무급으로 나누고, 고위급에는 원조의 목표, $\mathrm{ODA}$ 규모 확대 등 전략적인 측면에 치중하고, 실무급에서는 국별배분 방안, 유.무상연계 방안 등 좀더 실시적인 측면에 우선순위를 두었으면 한다.

반면 수원국에서의 $\mathrm{ODA}$ 관련부처간 정책대화도 강화되어야 할 것이다. 현재의 체제를 고려시 관 련 회의를 우리 대사관에서 주관하고 KOICA, KOTRA, 수출입은행, 개발 $\mathrm{NGO}$ 등이 참석하는 형태 가 적절할 것으로 판단된다. 이를 위해 $\mathrm{KOICA}$ 도 해외사무소에 파견된 직원들에게 더 많은 권한과 책 임을 부여하는 제도적 장치가 필요하다.

\section{다. ODA 전략틀 수립}

또 다른 방안으로는 $\mathrm{ODA}$ 관련 전략틀을 제정하여 원활한 원조조정을 실시하는 것이다. 현재 대부 분 선진 원조국들은 자체의 대외원조 전략틀 (strategic framework)인 원조헌장을 가지고 있다. 원조 헌장의 중요성을 살펴보면, 대내적으로는 원조실시기관이 많을 경우 각 부처의 원조정책 수립 및 조정 시 일관성 유지를 위한 기본 방향을 제공하고 있으며, 대외적으로는 수원국 및 타 공여국으로 하여금 자국이 나아가야 할 원조방향 및 분야를 알게 하여 이들과의 정책대화 및 원조조정회의 시 요구분야와 제공가능 분야간의 일관성을 갖도록 하는 역할을 수행한다.

그 형태로는 의회에서 비준되어 법으로 존재하는 경우, 정부차원에서 원조헌장을 선언하여 실시하 는 경우, 그리고 원조집행 부처의 내부 정책으로 존재하는 경우 등 크게 3 가지 형태로 나눌 수 있으며, 원조헌장에 자신들의 대외원조관련 기본목표, 세부 추진방향을 밝히고 있다하. 먼저 의회에서 비준하 
여 법으로 정해진 경우 의회에서 승인되었기 때문에 법적인 구속력이 강하며, 개도국에서 자국의 원 조에 대한 의지표명, 또한 법으로 원조의 목표, 구체적인 실천방향이 수립되기 때문에 원조정책의 일 관성, 조정이 용이하다는 장점이 있는 반면, 원조의 환경이 급변하는 시점에서 원조의 방향을 수정하 기 위해서는 의회의 승인을 획득해야 하기 때문에 많은 시간과 절차가 요구된다는 문제점도 있다.

두 번째 유형인 정부차원의 원조헌장 선언의 경우 정부의 원조에 대한 강한 의지 표명, 첫 번째 유 형보다 원조정책의 신축적인 운영이 용이하다는 장점이 있으며, 셋째 유형의 경우, 정부 및 의회의 간 섭이 상대적으로 적어 상황에 맞게 원조정책의 신축적인 운영이 가능하지만 대외원조정책에 정치적 인 측면이 많이 고려될 수 있다는 문제점도 있다.

우리의 경우 원조헌장의 중요성에도 불구하고 아직까지 이를 지니고 있지 않다. 그 이유를 살펴보 면 정부, 국회 및 국민들의 국제협력에 대한 인식이 높지 않기 때문이다. 그러나 이번 인도네시아 지진 해일사태 등 범세계적인 문제에 효율적으로 대처하고 $\mathrm{OECD}$ 회원국으로서 국제사회가 요청하는 우리 의 역할을 잘 수행하기 위해서는 우리의 국제협력 방향과 정책을 대외적으로 공표하는 것이 필요하 다. 이 헌장에 포함될 내용으로는 원조의 기본목표와 원조규모, 국별배분, 원조수단 및 분야 등을 포 함하는 세부추진 방향이 적시되어야 할 것이다.

\section{2. 국제적 조정}

\section{가. 정책대화}

우리나라는 수원국과의 정책조정을 위해 원조공여국 회의 ${ }^{17}$ 에 참석하고 있으며, 공여국과는 원조 정책 협의회를를 개최하여 원조조정을 실시하고 있다. 전자의 경우는 대개 World Bank나 UN이 주최 하는 다자간회의 형식이지만 동시에 우리나라와 수원국간의 양자간 경제협의회를 통해 양국간 원조 정책에 관한 조정도 실시하고 있다.

원조조정기능을 더욱 강화하기 위해서는 양 - 다자간 원조기관에서 개최하는 수원국 원조협의회에 적극적으로 참여하여 우리가 필요한 역할을 수행할 뿐만 아니라, 이 회의를 통해 우리 기업들이 개발 도상국 원조사업에 참여할 수 있는 정보 및 기회를 확보하는 것이 중요하다 ${ }^{19)}$.

16) 현재 법의 형태로 전략적 틀을 가진 나라는 미국, 룩셈부르크, 스위스를 들 수 있으며, 국가의 정책으로 선언한 국가는 일본, 카나다, 영국 등이고, 특별 한 형태가 없이 원조기관내의 내부정책의 형태를 가진 국가로는 프랑스, 스페인을 들 수 있다. 
또 다른 수원국과의 조정방안으로는 동 국가에 대한 국별 프로그램(country programming)을 실 시하는 방안을 들 수 있다. 국별 원조계획은 해당 수원국의 특수한 사정을 고려하여 관련 국가에 가장 적합한 중. 장기적 원조정책의 수립 및 실시라고 정의할 수 있는데, 현재 각 공여국은 기존의 프로젝트 별 원조를 지양하고, 국별원조를 실시하기 위한 기반을 구축하는데 많은 노력을 경주하고 있다이. $\mathrm{OECD} / \mathrm{DAC}$ 회원국들의 국별 원조계획 내용을 살펴보면 관련 수원국에 대한 공통적인 사항으로는 그 국가의 정치적, 경제적 상황에 대한 심층분석, 관련 국가의 중장기 개발계획 및 개발 우선순위 파악, 이를 근거로 한 자국의 원조 전략 및 문제점, 타 공여국의 원조공여 실태분석이며, 차이점으로는 어떤 회원국은 국별계획에 중.장기적 구체화된 원조사업, 그리고 이를 실천하기 위한 원조규모를 명시하기 도 하며, 어떤 회원국들은 국별 원조계획을 수립하기 전 수원국의 참여를 의무적으로 명시하여 수원국 의 우선순위가 정책수립 과정에 반영되도록 하고 있다리.

$\mathrm{KOICA}$ 의 경우 $\mathrm{ODA}$ 예산 규모가 점차 확대되는 추세에 있으며, 이제 프로젝트 원조뿐만 아니라 프 로그램 원조 등 비프로젝트 원조를 실시해야 하는 시점에 도달했기 때문에 중점 협력대상국을 중심으 로 국별 계획을 수립하여 시범적으로 실시하는 것이 어떨까 한다. 이를 통해 수원국과의 원조정책 협 의시 수원국의 필요분야와 함께 우리가 필요하다고 판단되는 분야도 함께 제시하여 단순한 수요중심 방식(Demand driven)이 아닌 협의방식(Consultative basis) 원조를 실시할 수 있는 기반을 조성하 는 것이 필요하다.

\section{나. 원조기관간의 협의 강화}

타 공여기관과의 정책대화는 사업의 효율성을 위해서는 반드시 필요하다. 협의 방안은 크게 정책레 벨과 사업레벨로 나눌 수 있다. 정책별로는 공여국과의 정책협의회 개최를 들 수 있다. 예를 들면 우리 나라는 현재 일본이나 스웨덴과는 정기적으로, 카나다와는 비정기적으로 회의를 개최하고 있다. 특히 일본과의 회의에서는 $\mathrm{KOICA}$ 와 JICA간의 협력방안도 구체적으로 협의되기도 하였달․

19) DAC회원국들은 현재 개도국에게 제공하는 원조의 비조건화(untied)비율 높여가고 있으며, 최근에는 최빈국에 대한 원조를 완전히 비조건화 하려고 회 의를 개최하고 있다. 이는 다른 선진공여국들이 수원국에게 제공하는 각종 프로젝트사업이 공여국자체 기업이 아닌 국제입찰에 의해서 결정됨을 의미하 며, 특히 해외건설, 토목사업에서 높은 노하우 및 기술을 지닌 우리 기업의 입장에서는 사업을 수주할 수 있는 좋은 기회라고 볼 수 있다.

20) '90년대 이전의 원조전략은 프로젝트형 원조라고 할 수 있는데, 이는 분야별로 미시적으로 접근하여 실시하는 전략을 의미하며, 문제점으로는 각각의 프로젝트가 종합적인 국별개발계획에 연결되지 못한다는 점이다. 반면에 ' 90 년도 이후에는 각 공여국은 국별원조를 위한 제도적 틀을 마련하였으며, 이를 통해 관련 수원국에 대한 개개별 프로젝트가 종합 개발계획과 연계되게 하여 시너지효과를 극대화하는 전략을 수립하고 있다.

21) 스위스의 경우 의회에서 4년마다 원조항목을 정기적으로 검토하고 있는데 이는 단년도 예산제도의 문제점을 극복하고자 만들어진 제도이다. 스위스는 원조항목을 만들기 전 수원국과의 원조협의를 실시하고 있으며, 이를 통해 수원국의 우선순위를 반영케 하고 있다.

22) 2004년에 서울에서 개최된 한.일 원조정책협의회에서는 KOICA와 JICA간 공동연수의 지속적 추진 및 확충, 사업평가 역량강화를 위한 협력 및 양 기 관간 직무연수 상호추진이 합의되었다. 
사업별로는 공여국간 원조협의회에 참석하여 공동으로 실시할 수 있는 사업을 발굴하거나, 혹은 완료된 사업에 대한 공동평가 등에 대한 협의를 하는 것도 필요하다. 공동평가의 경우 평가에 대한 경 험 및 노하우를 축적하기 위해 다자간 원조기관이나 양자간 원조기관과의 협조를 통해 합동평가회의 에 적극 참가하는 것이 좋을 것이다. 다자간 원조기관의 경우 평가에 대한 경험과 노하우가 많이 축적 된 세계은행이나 UNDP, 양자간 원조기관으로는 우리나라와 원조형태 및 수단이 유사한 일본과의 협 력이 적절하리라 판단된다.

또 다른 협력방안으로는 $\mathrm{KOICA}$ 해외사무소의 역할이 강화되어 수원국에 파견된 공여국들의 공식 모임인 정책협의회에 참여하여 정책대화를 강화하거나, 또는 봉사단 사업 등 실무적인 측면에서 다 른 국가에서 파견된 단원과의 network 강화, 공동 프로젝트 실시, 정보공유 등을 실시하게 되면 공여 국간의 조정이 더욱 효율적일 것이다.

마지막으로 공여국의 원조사업을 원활히 조정하기 위해 $\mathrm{OECD} / \mathrm{DAC}$ 에 가입하는 것도 필요하다. 이를 통해 회원국간의 업무협의를 원활히 하고, 국제협력의 흐름을 잘 관찰하여 우리의 나아갈 방향 을 정립하는 것도 우리의 효율적인 원조실시에 반드시 필요한 과정이라 할 수 있다 ${ }^{23}$.

\section{IV. 결론}

이번 인도네시아 해일사태는 원조액보다 더욱 중요한 것이 수원국정부에서 ownership을 가지고 조정에 대한 리더쉽을 발휘하는 것임을 잘 말해주고 있다. 수많은 공여국과 공여기관, 국내외 NGO, 시민단체들이 원조공여 의사를 밝혔지만 더욱 중요한 것은 공여되는 원조액과 수단을 어떤 전략으로 활용하는 가에 원조의 성패가 달려있기 때문이다. 다행히 동 사태 후 인도네시아에서 개최된 특별정 상회의에서 원조공여국간의 조정은 UN이 맡기로 합의되었다. 그러나 무엇보다 더욱 중요한 것은 다 자간 및 양자간 기관간의 조정, 또한 수원국과의 조정이다.

원조조정은 원조의 효율성과 직접적으로 연관되어있기 때문에 $\mathrm{DAC}$ 는 원조조정의 중요성을 인식 하고 이에 대한 원칙을 제정하였으며, 최근에는 원조실시에 있어서 파트너쉽 강화를 위한 제원칙을 만들고, 정책조화성에 대한 여러 국제회의를 개최하여 그 중요성을 강조하고 있다. 이는 원조조정이 $\mathrm{MDGs}$ 를 달성하기 위한 필수조건으로 인지되기 때문이다.

이와 같은 점을 고려하여 본 소고는 원조조정의 개념, 종류 및 선진국의 경우를 중심으로 우리의 현 
황을 살펴보고 향후 나아갈 방향도 살펴보았다. 향후 우리가 추진해야 하는 과제는 국내적 조정을 좀더 효율적으로 수행할 수 있는 제도적 장치를 마련하는 것이다. 그 방안으로 ODA 수행기관의 통합, ODA 담당기관간의 정책대화 강화, 그리고 $\mathrm{ODA}$ 관련 원조헌장(법)을 제정하는 것을 제시하였다.

반면 국제적 조정으로는 UN이나 World Bank 등 국제기구에서 개최하는 원조공여국 회의에 적극 적으로 참여하여 우리의 의사를 구체적으로 밝히거나, 아니면 원조 공여기관간 양자간 회의를 정례화 하여 양국간 공동으로 실시할 수 있는 사업을 발굴하거나 동 사업에 대한 공동평가를 실시하는 것이 바람직하다고 판단되며, 가까운 시기에 $\mathrm{OECD} / \mathrm{DAC}$ 에 가입하여 회원국간 원조조정 과정에 직접 참여 하는 것도 좋을 것이다. 마지막으로 수원국과의 양자간 협의도 강화하여 수요중심이 아닌 협의중심적 인 원조방식을 채택하는 것이 좋을 것이라 본다. 이를 위해서 Country Programming을 실시하여 수 원국별 차별화 원조방식을 실시하는 과정이 필요할 것이다. 
1. 동 원리는 다양한 상황에서 신축적으로 활용되어야함. 그리고 이 원리는 외부의 원조에 의존해 야 하고 따라서 자원의 효율적인 분배를 위한 국제적 원조 조정이 필요한 개도국에게 적용되어 야 함. $\mathrm{DAC}$ 회원국은 원조정책과 우선순위조정의 모든 책임과 원조조정 업무는 개도국에게 있 다는 사실을 인정함

\section{선진국의 협력으로 개도국이 투자와 지출을 위한 정책의 향상과 평가력의 향상을 도와야 함.}

2. 개도국은 그들의 자체 및 외적자원의 효율적이고 조정된 사용을 위해 잘 고안된 정책과 신중하 게 심사된 투자 및 지출 프로그램이 요구됨

3. DAC회원국은 구조조정프로그램의 체계화에 있어서 World Bank/ IMF의 중요성을 인지함. 구 조조정 프로그램에서 성장을 추구하도록 하는 최근의 방향을 환영함. 그들은 또한 구조조정프로 그램이 형평과 소득분배문제를 고려해야하며, 교육, 보건, 인구 및 환경과 같은 인력 관련 주제 가 예산 배분 및 전략수립에 있어서 고려되기를 원함. 이 프로그램이 장기적으로는 선진국의 민 간자본이 개도국으로 유입되기 양호한 조건을 만드는데 일조할 수 있음을 인식함

4. $\mathrm{DAC}$ 회원국은 개도국이 스스로 원조정책과 프로그램을 효율적으로 고안하고 집행할 수 있게 하 는 분석적 관리능력이 강화될 수 있도록 선진원조기관의 도움이 필요함을 강조함. 또한 회원국 들은 개도국이 정책과 프로그램을 개선하는 것을 돕고 고비용인 분석적 준비 작업을 제공하는 데 있어서 양자간 원조 기관들이 더욱 참여해야 하는 필요성을 인식함. 다자간 원조기구들이 이 와 같은 역할의 수행에 유리한 면이 있지만 양자간 기구도 그들이 특별한 전문성을 가진 분야에 서 이와 같은 역할을 수행해야 함. 회원국들은 이 분야에 기여하기 위한 역량 강화의 필요성에 대해서 검토해야 함

5. 회원국들은 신중하게 심사되었고 생산적인 투자 프로그램을 수행하는데 공여국과 수원국 모두 가 이 원리를 계속 실시함의 필요성을 강조. 이 프로그램이 국제재정기관의 충고와 도움을 받아 신중하게 검토되고 논의될 경우 원조배분에 있어서 유용한 기조를 제공함. 이 프로그램의 정기 적 심사는 우선순위에 대한 의견교환과 진행사항의 점검기회를 제공. 이것은 또한 원조조정의 중요한 기초를 제공함

6. 회원국들은 현재 정책향상노력을 실시하고 있는 개도국에게 이에 필요한 적절한 재정적 도움의 
중요성을 인지함. 이것은 긴급하게 수입이 필요한 분야의 재정적 수요를 위해 빠르게 제공될 수 있는 기금마련을 필요로 함. 공여국들이 개도국에게 중.장기자금 제공가능성을 암시하는 것이 그들의 구조조정노력을 가속화함

7. 즉각적으로 실시해야 하는 경우에 재활과 기존의 역량을 더 잘 활용하는 것이 강조될 필요가 있 다. 이와 같은 목적을 가진 프로그램은 새로운 프로젝트의 실시보다는 더욱 우선순위를 부여해 야함. 회원국들은 반복적으로 발생하는 경상비와 정비요구에 대해 현실적인 지급의 필요성을 인 지함. 그러나 이것은 반드시 개도국의 자조능력 향상에 대해 서로 합의하면서 시행해야 함

8. 회원국들은 개도국의 중요한 프로젝트나 분야별 프로그램의 협조융자에 있어서 많은 회원국들이 함께 참여하는 것에 특별한 장점이 있음을 인지. 이와 같은 경우 양자간기구나 다자간기구 중 중 요한 역할을 하는 기구에 의해 평가 작업이 주도되기 때문에 개도국의 행정적인 부담이 경감됨

9. 수출신용은 특별한 경우에는 저소득 국가들에게도 도움이 될 수 있음. 그러나 이때에는 반드시 원조의 목적과 투자프로그램이 신중하게 심사되어야 한다는 개발 원칙이 지켜져야 함

10. 외채에 대한 의무는 개도국의 재정에 많은 영향을 끼침. 파리클럽이 주도하는 빚의 경감에 있어 서 개도국의 중.장기적 성장을 위한 구조조정의 성격과 요구에 대한 모든 정보가 제공되어야 함

\section{원조조정의 향상된 기획을 위한 후속조치들}

\section{- 공여국, 수원국, 국제 기구들간의 협력}

11. 회원국들은 진정한 의견일치에 기초하여 시행 가능한 결론을 도출 하기 위한 국제적 원조조정 노력에 있어서 개도국, 다자간 원조기구 및 다른 원조기관과 협력하겠다는 의지를 재확인함

12. 회원국은 수원국 정부와 국제기구간의 밀접한 협력의 필요성을 인정함. 그러나 양 측이 정책 및 프로그램을 협의하고 형성하는 과정에 공여국들과의 협의 및 조정과정의 필요성을 인지함 13. 공여국간 그리고 공여국 및 개도국간에 진행 중이거나 계획을 하고 있는 사업에 관해 모든 그리 고 솔직한 정보교환이 성공적인 원조조정이나 효율적인 원조집행의 필수적임을 인지함 


\section{$\checkmark$ 협의그룹과 라운드 테이블}

\section{(Consultative Groups and Round Tables: CGRT)}

14. 회원국들은 CGRT의 최근의 향상을 치하하고 이를 이끌어가는 원조기관이 다음의 방향으로 추구하기를 원함

15. 가능한 지역별 그룹을 이용하여 CGRT전의 상담회의에 양자간 원조기관들이 많이 참석하기를 원함. 이들의 참석이 수원국에 대한 개발 정책과 프로그램에 대한 의견일치를 끌어내는데 필수 적이기 때문임

16. 핵심 사업이나 정책 쟁점에 대해 솔직하고 실질적으로 의견교환을 할 수 있도록 CG의 형태를 수정함. 이러한 노력은 또한, 분야별 정책과 투자 프로그램에 주안점을 두고 수원국의 투자계 획을 검토하고, 수원국의 구조조정에 있어서 원조의 의미에 관한 논의하고, 수원국의 무역추 세 및 채무 관련사항을 포함하는 개도국의 전반적인 재정상황을 결정하는 요소에 대해 고려하 기 위함임

17. 재정적인 지원만큼 중요한 것으로 기술 원조를 강조하며 기술원조의 수요와 우선순위를 판별 하고 관련 프로그램을 만드는 것에 대한 관심을 고양함

18. CGRT에서 결정된 결론을 구체적이고 행동 지향적으로 기록할 것, 그리고 개도국의 조정에 참여하는 그룹을 포함하여 이에 관심을 가진 조직이 편람가능하게 함

19. CGRT에서 도출되는 행동을 좀더 효율적으로 실현하며, 특히 분야 및 개도국 내부에서의 자체 회의를 통해 개도국의 정책개혁의지의 천명과 원조제공에 대한 공여국의 명확한 의도가 나타 나야함

20. 회원국들은 특히 UNDP가 최근에 주도한 RT 강화에 고무를 받음. 개도국의 적극적 참여 권 장, 정책개혁의 강조, UNDP 인력 강화, 개도국 및 참석자의 선택에 효율적인 접근, 분석력 개 선과 개도국 내 후속조치, World Bank와의 긴밀한 협력을 통한 RT 준비, 개도국 및 공여국 의 적절한 대표의 선정 장려, $\mathrm{UNDP}$ 에 의한 회의 주도 등을 통해서, $\mathrm{UNDP}$ 는 조정자로서의 역할을 좀 더 효과적으로 수행할 수 있도록 역량을 강화함

21. 또한 RT의 두번째 단계인 당사자급의 회의를 강화하여 개도국 정부가 자신들의 조정 정책을 추진할 의지를 천명할 기회, 선진국이 그 프로그램들을 지지하는 것을 공언할 수 있는 기회를 주는 것이 필요함 


\section{지방별, 분야별, 그리고 지역별}

22. 회원국들은 개도국내에서 중앙 및 지방단체간의 강력한 연계를 설치하기위해 또한 이들 간의 원조 조정력을 강화할 필요성을 인지. 중앙조정장치는 지방/분야별로 담당할 이슈를 구별함으 로써 지방 및 분야간의 조정에 주도권을 주어야 함. 정책대화는 지방 및 분야별 원조조정에 본 질적인 요소이여야 하며, 중앙 정부는 이러한 절차의 중심에 있어야 함. 개도국의 지방에 근무 하는 공무원들의 이 과정에의 참여가 필요함. 그러나 분야별 원조정책이나 프로그램에 관련된 결정에 있어서는 중앙정부의 재정 및 기획담당직원의 참여가 중요함

23. 최근에 수원국내에서 원조조정의 확대가 이뤼짐. 이를 통해 정보교환, 중복프로젝트의 회피, 그리고 프로젝트에의 공동참여가 이루어짐. 그러나 신중하게 심사되고 검토된 투자사업 그리 고 분야별 정책과 프로그램의 개발과 실시에 관한 것에 대해서는 향상되어야할 여지가 남아 있음. 회원국은 수원국이 주도하는 효율적 감독, 조정기구의 설립을 환영함. 그리고 이와 같은 수원국내의 조정기구는 분명한 설립이유와 근거가 필요함

24. 회원국들은 신중하게 심사를 받은 투자 및 지출 사업에의 지지와 준비, 자본과 경상비에 대한 현실적인 재정 예상을 고려하여 개선된 분야별 접근법의 중요성을 강조함. 또한 효율성을 고 양하고 절차를 조화롭게 함으로써 행정비용을 경감하기 위해서, 원조를 분야별로 분류해야할 필요성을 강조. 협조융자장치가 이를 달성하기위한 도구로 활용될 수 있음

25. 회원국들은 지역발전은행이 정책대화와 특히 분야별 차원에서의 개혁과정에 참여하는 것의 중요성을 인지함. 또한 이 은행들이 거시적 경제 정책틀 안에서 UNDP나 World Bank와 밀접 하게 협력하면서 활동하는 것이 중요함

26. 아프리카에서 CILSS/Club du Sahel 과 SADCC와의 틀 안에서 지역 맥락에서의 원조 수요을 고려하여 지역협력을 장려하였던 것처럼, 조정의 지역적 접근법은 국별조정 과정에 중요한 보 완을 할 수 있음

\section{조직별 그리고 직원별}

27. 회원국들은 수원국의 행정능력의 과부하를 피해야 하는 필요성을 인지함. 원조의 집행을 능률 화 하는 것은 쉽지 않지만 회원국들은 수원국과의 업무수행에 있어서 기존의 여러 보고서 및 
연구 자료를 기초로 하여 수원국의 원조수행절차의 간소화 및 조화의 기회를 찾고자함. 이것 은 의회 및 행정부에 의한 요구사항의 수정을 수반하기도 함

28. 회원국은 이 과정을 담당하는 직원들의 경제 및 정책에 대한 전문성의 중요성을 인지함. 또한 수원국에서의 정책대화 및 원조사업에 있어서 효율적인 참여를 위해서는 수원국 내에 공여국 원조기관에서 파견된 정책전문 직원의 참여가 필요. 이를 위해 원조기관들에게 있어서 현지에 자체직원들의 증원, 직원들의 재훈련 및 직원 충원 정책 조정, 민간 전문가의 효율적인 활용이 필요함을 의미함

29. 회원국들은 수원국이 스스로 효율적인 정책 및 프로그램의 고안과 실시 및 그들의 발전과정의 관리를 위한 능력배양의 중요성을 강조함. 능력 있는 중앙정부기관의 존재는 효율적인 정책 틀을 수립하는데 필수적임. 그러나 무엇보다도 분야별, 지방단체별 차원에서의 광범위한 제도 적 발전노력이 필요함. 제도발전을 위해 민간분야의 역할이 중요하므로 민간분야의 잠재력과 능력도 고려되어야 함

\section{$\checkmark$ 실시 및 후속조치}

30. 회원국들은 지금까지 정한 원칙을 실시하기위해 자체의 조직 내에서 적절한 행동을 실시해야함 
· 권율(1999), OECD/DAC의 공적개발원조 논의와 동향, 대외경제연구원

· 장현식(1999), OECD/DAC회원국의 원조체제 비교분석 및 우리의 국제협력 방향, 장현식(2000), 아국의 OECD/DAC 가입 시 기대효과 및 향후 추진방향

· 한국국제협력단(1999), 21세기 한국개발 $\mathrm{NGO}$ 의 활동 전략

· 한국국제협력단(1999), 국제협력의 범세계적 이슈와 우리의 정책방향

· 한국국제협력단(2001), 한국국제협력단 10년(1991-2000)

- UNDP 한국대표부(1998), 빈곤퇴치

- Browne, Stephen(1990), Foreign Aid in Practice, New York, New York University Press

- Chang, Hyun-sik, Arthur M. Fell and Michael Laird(1999), A Comparison of Management Systems For Development Cooperation in OECD/D AC Members, OECD

- Kim, Sang-tae \& Seddon, David, ODA Policy and Practice: The Republic of Korea (2004)

- Ministry of Foreign Affairs, Republic of Korea(2002), Korea's Official Development Assistance,

OECD(1992), DAC Principles For Effective Aid,

OECD(2002), DAC Peer Review of United States

OECD(2003), DAC Peer Review of Denmark

OECD(2004), DAC Peer Review of France

OECD(2004), DAC Peer Review of Japan

- UNDP(1998), UNDP Poverty Report 1998: Overcoming Human Poverty, New York,

- UNDP(1999), Global Public Goods: International Cooperation in the 21st Century, New York Oxford, Oxford University Press

- UNDP(2005), Investing in Development: A Practical Plan to Achieve the Millennium Development Goals, Earthscan

- World Bank(1998), Assessing Aid: What Works, What Doesn't and Why, Oxford University Press 